\title{
Sistem Informasi Penilaian Improvement Activity (KAIZEN) Menggunakan Metode TOPSIS pada PT. Yoshikawa Electronics Bintan
}

\author{
Ade Winarni ${ }^{1}$, Hejli Sandi Manik ${ }^{2}$ \\ ${ }^{1}$ Teknik Informatika Sekolah Tinggi Teknologi Indonesia Tanjungpinang \\ Jln. Pompa Air No. 28, Bukit Bestari, Tanjungpinang, Kepulauan Riau, Indonesia 29122 \\ 1ade@sttindonesia.ac.id \\ ${ }^{2}$ Program Studi Teknik Informatika Sekolah Tinggi Teknologi Indonesia Tanjungpinang \\ Jln. Pompa Air No. 28, Bukit Bestari, Tanjungpinang, Kepulauan Riau, Indonesia 29122 \\ ${ }^{2}$ hejli_sandi@yahoo.com
}

\begin{abstract}
Intisari- Permasalahan Manajemen penilaian terhadap evaluasi kinerja pada perusahaan yang dilakukan secara tidak terstruktur dan dengan proses manual akan menyebabkan sistem pengambilan keputusan oleh pimpinan tidak akurat. Hal ini tentu akan sangat merugikan perusahaan asing terutama pada PT.Yoshikawa Electronics Bintan yang merupakan perusahaan bergerak dibidang Lampu LED. Penelitian ini bertujuan untuk menganalisa semua faktor-faktor penghambat pada proses evaluasi kinerja terhadap aktivitas kaizen (improvement activity) yang akan dipecahkan dengan suatu sistem integrasi dengan metode TOPSIS untuk menyederhanakan proses penilaian kerja secara manual menjadi proses satu pintu secara otomatis. Pada sistem yang sedang berjalan, perusahaan PT.Yoshikawa Electronics Bintan masih menggunakan sistem manual yang harus mencatat setiap data hasil kinerja suatu aktivitas kaizen dan menyerahkan formulir Kiazen untuk proses penilaian. Yang kemudian hasil penilaian masih akan di proses secara ulang di input ke dalam Microsoft Excel. Dengan metode Topsis dapat mengakomodir kebutuhan, karena sistem ini mampu memberikan value/nilai pada setiap kegiatan/pekerjaan dalam organisasi dengan lebih obyektif, sesuai dengan beban setiap pekerjaan masing-masing, sehingga mengurangi perdebatan dalam penyusunan kebijakan tentang compensation. Hasil dari penelitian ini dimaksudkan untuk membangun suatu program aplikasi sistem pendukung keputusan untuk perengkingan kaizen yang mempercepat terlaksananya suatu proses penilaian aktivitas kaizen. Program aplikasi dibangun terintegrasi dengan metode TOPSIS.
\end{abstract}

Kata kunci — kaizen, TOPSIS, Evaluasi Kinerja, Sistem Pendukung Keputusan.

\section{Pendahuluan}

Perkembangan teknologi komputer, menjadikan komputer sebagai suatu media sarana penting dalam dunia teknologi informasi. Komputer dapat mengolah data yang diinginkan sesuai dengan kebutuhan suatu instansi atau perusahaan. Salah satu manfaat komputer adalah penerapan komputer pada sistem informasi suatu perusahaan pemerintah maupun swasta yang sangat dibutuhkan karena perkembangan teknologi yang sangat pesat menuntut suatu perusahaan untuk memperoleh informasi yang lebih cepat dan akurat. Sistem informasi yang mendukung membuat kinerja suatu perusahaan akan terlaksana dengan baik dan dapat menangani berbagai pengolahan data dengan menggunakan teknologi informasi. Adanya sistem informasi yang tepat dan akurat dapat mengurangi terjadinya kesalahan yang tidak diinginkan sehingga dapat meningkatkan kinerja yang lebih efisien dan kecepatan operasional suatu perusahaan.

Salah satu perusahaan swasta asing yang saat ini sedang beroperasi di kawasan Lobam, Bintan adalah PT.Yoshikawa Electronics Bintan yakni perusahaan manufacturing yang bergerak dibidang elektronik seperti pembuatan lampu LED (light-emitting diode) dan pembuatan chip yang menerapkan sistem improvement activity (kaizen) untuk mengidentifikasi proses-proses yang perlu diperbaiki atau ditingkatkan dan juga melakukan evaluasi terhadap prosedur dan standarisasi pekerjaan yang telah ada ataupun menetapkan standar baru dalam pekerjaan untuk menunjang kegiatan produksi.

Permasalahan yang terjadi pada proses penilaian improvement activity (kaizen) di PT.Yoshikawa Electronics Bintan dimana proses penilaian masih menggunakan sistem manual. Pada proses ini dimana setiap improvment activity yang telah dilakukan oleh karyawan akan diolah melalui proses penilaian secara manual dimana Plan Manager harus memeriksa apakah suatu kegiatan improvement yang telah diberikan karyawan tersebut sudah memenuhi syarat untuk kriteria yang sudah ditentukan dan proses ini membutuhkan waktu 10 sampai 20 menit per form improvement activity (kaizen) yang sangatlah memakan waktu yang cukup lama yang disebabkan oleh banyaknya data yang masuk sehingga Plan Manager dapat menghabiskan waktu hingga satu minggu untuk proses penilaian dan juga sering kali terjadi penilaian yang tidak sesuai akibat pencatatan secara manual karena 
ditulis pada form kaizen application berupa kertas kerja yang sering mengakibatkan hilangnya data tersebut.

Selain itu proses pembuatan data laporan hasil penilaian yang dilakukan secara manual dengan cara Plan Manager melakukan input data menggunakan aplikasi Ms.Excel memungkinkan terjadinya kesalahan pada saat proses input data dan mebutuhkan waktu yang relatif lama.

\section{MEtodologi PENELITIAN}

\section{A. Metodologi Pengumpulan Data}

Dalam kegiatan untuk memperoleh data pada penelitian skripsi ini, penulis menggunakan teknik pengumpulan data yang digunakan adalah sebagai berikut:

1. Observasi

Melakukan observasi atau peninjauan tempat di PT.Yoshikawa Electronics Bintan sebelum pelaksanaan kegiatan pengumpulan data dengan mengadakan pengenalan terhadap objek skripsi, aktivitas kerja dan bahan kajian.

2. Wawancara

Melakukan wawancara langsung dengan pihak yang terlibat dalam sistem perusahaan tersebut salah satunya adalah Manager perusahaan.

3. Studi Kepustakaan

Melakukan pengumpulan data secara tidak langsung dengan melakukan studi kepustakaan, yaitu dengan mengumpulkan data-data dan teori-teori dari berbagai buku atau literatur yang berhubungan dengan penulisan skripsi ini.

\section{B. Metode Pengembangan Perangkat Lunak}

Prosedur pengembangan yang digunakan pada aplikasi ini adalah menggunakan prosedur pengembangan model waterfall[4]. Metode Waterfall (Classic Life Cycle) yang menyarankan pengembangan perangkat lunak secara sistematik dan berurutan yang dimulai dari tingkatan sistem tertinggi dan berlanjut ketahap analisis, desain, coding, testing atau pengujian dan pemeliharaan. Model ini disebut dengan waterfall karena tahap demi tahap yang dilalui harus menunggu selesainya tahap sebelumnya dan berjalan berurutan.

\section{HASIL DAN PEMBAHASAN}

\section{A. Analisis Kelemahan Sistem}

Tahap yang dilakukan penulis dalam menganalisis data adalah dengan menentukan permasalahan yang terjadi dalam aplikasi. Dari hasuil pengamatan yang dilakukan penulis permasalahan yang dihadapi adalah sebagai berikut:

1. Proses penilaian improvement activity (kaizen) masih dengan cara manual dapat memperlambat proses pemberian nilai pada setiap karyawan yang sudah memberikan improvement activity (kaizen) yang telah dilakukan.

2. Penyimpanan hasil penilaian improvement activity (kaizen) belum terorganisir dengan baik, sehingga sering terjadinya kehilangan data yang tidak disengaja.
Pembuatan laporan hasil penilaian masih secara manual sehingga membutuhkan waktu yang relatif lama.

\section{B. Studi Kasus Menggunakan Metode TOPSIS}

Didalam proses improvement activity (kaizen) pada PT.Yoshikawa Electronics Bintan ingin melakukan penilaian dan melakukan pengambilan keputusan dalam perengkingan kaizen . Ada tiga improvement activity yang akan jadi alternatif yaitu A1, A2 dan A3. Berikut adalah langlah-langkah untuk menentukan jawaban permasalahan di atas.

1. Menentukan Kriteria

Data kriteria didapat dari pendekatan subjektif yaitu nilai bobot ditentukan berdasarkan subjektifitas dari para pengambil keputusan yaitu dalam hal ini khususnya yaitu Plant Manager PT.Yoshikawa Electronics Bintan. Adapun kriteria tersebut adalah safety, quality, delivery/inventory, cost/man hour reduction, dan innovation/creativity.

Rangking kecocokan pada setiap kriteria, dinilai dengan 1 sampai 5 dan bobot dari masing-masing kriteria adalah 5 . Tabel 1 adalah tabel kriteria penilaian kaizen beserta nilai setiap kriteria:

TABEL 1

\section{KRITERIA/FAKTOR POIN PENILAIAN KAIZEN}

\begin{tabular}{|l|c|c|c|c|c|c|c|}
\hline \multicolumn{1}{|c|}{ Kriteria } & Bobot & Mencoba & Berusaha & Memuaskan & Ideal & Istimewa & Keterangan \\
\hline safety & 5 & 1 & 2 & 3 & 4 & 5 & benefit \\
\hline Quality & 5 & 1 & 2 & 3 & 4 & 5 & benefit \\
\hline Delivery/nventory & 5 & 1 & 2 & 3 & 4 & 5 & benefit \\
\hline CostMan hour Reduction & 5 & 1 & 2 & 3 & 4 & 5 & benefit \\
\hline imovation/creativity & 5 & 1 & 2 & 3 & 4 & 5 & benefit \\
\hline
\end{tabular}

2. Menentukan Nilai Matriks

Matriks keputusan adalah matriks nilai setiap kriteria yang dimiliki oleh aktivitas kaizen. Berdasarkan tabel 1 ditentukan nilai matriks keputusan dasa pada setiap aktivitas kaizen. Untuk lebih jelasnya dapat dilihat pada tabel 2 berikut:

TABEL 2

NILAI MATRIKS

\begin{tabular}{|c|c|c|c|c|c|}
\hline \multirow{2}{*}{$\begin{array}{l}\text { Nama } \\
\text { Karyawan }\end{array}$} & \multicolumn{5}{|c|}{ Kriteria } \\
\hline & Safety & Quality & $\begin{array}{l}\text { Delivery/ } \\
\text { Inventory }\end{array}$ & $\begin{array}{l}\text { Cost/Man } \\
\text { Hor } \\
\text { Reduction }\end{array}$ & $\begin{array}{l}\text { Innovation/ } \\
\text { Creativity }\end{array}$ \\
\hline A1 & 4 & 4 & 5 & 3 & 3 \\
\hline A2 & 3 & 3 & 4 & 2 & 3 \\
\hline A3 & 5 & 4 & 2 & 2 & 2 \\
\hline
\end{tabular}

3. Membuat normalisasi Matriks Menggunakan Persamaan Perhitungan Sebagai Berikut

$$
r_{i j}=\frac{x_{i j}}{\sqrt{\sum_{i=1}^{m} x_{i j}^{2}}}
$$

Setelah melakukan hasil nilai matriks didapat kemudian dilakukan perhitungan normalisasi matriks keputusan untuk setiap aktivitas kaizen berdasarkan kriteria. Untuk membuat matriks ternormalisasi setiap nilai aktivitas kaizen dibagi dengan bobot pembaginya. Sehingga diperoleh perhitungan sebagai berikut: 


$$
\begin{aligned}
& r_{i j}=\frac{4}{\sqrt{4^{2}+3^{2}+5^{2}}}=\frac{4}{7.0711}=0,566 \\
& r_{i j}=\frac{3}{\sqrt{4^{2}+3^{2}+5^{2}}}=\frac{3}{7.0711}=0,424 \\
& r_{i j}=\frac{5}{\sqrt{4^{2}+3^{2}+5^{2}}}=\frac{5}{7.0711}=0,707 \\
& r_{i j}=\frac{4}{\sqrt{4^{2}+3^{2}+4^{2}}}=\frac{4}{6,4031}=0,625 \\
& r_{i j}=\frac{3}{\sqrt{4^{2}+3^{2}+4^{2}}}=\frac{3}{6.4031}=0,469 \\
& r_{i j}=\frac{4}{\sqrt{4^{2}+3^{2}+4^{2}}}=\frac{4}{6,4031}=0,625 \\
& r_{i j}=\frac{5}{\sqrt{5^{2}+4^{2}+2^{2}}}=\frac{5}{6,7082}=0,745 \\
& r_{i j}=\frac{4}{\sqrt{5+4^{2}+2^{2}}}=\frac{4}{6,7082}=0,596 \\
& r_{i j}=\frac{2}{\sqrt{5^{2}+4^{2}+2^{2}}}=\frac{2}{6,7082}=0,298 \\
& r_{i j}=\frac{3}{\sqrt{3^{2}+2^{2}+2^{2}}}=\frac{3}{4,1231}=0,728 \\
& r_{i j}=\frac{2}{\sqrt{3^{2}+2^{2}+2^{2}}}=\frac{2}{4.1231}=0,485 \\
& r_{i j}=\frac{2}{\sqrt{3^{2}+2^{2}+2^{2}}}=\frac{2}{4.1231}=0,485 \\
& r_{i j}=\frac{3}{\sqrt{3^{2}+3^{2}+2^{2}}}=\frac{3}{4,6904}=0,64 \\
& r_{i j}=\frac{3}{\sqrt{3^{2}+3^{2}+2^{2}}}=\frac{3}{4,6904}=0,64 \\
& r_{i j}=\frac{2}{\sqrt{3^{2}+3^{2}+2^{2}}}=\frac{2}{7.6904}=0,426 \\
& S i i
\end{aligned}
$$

Sehingga didapat hasil matriks ternormalisasi pada tabel 3 sebagai berikut:

Tabel 3 Matriks Ternormalisasi

\begin{tabular}{|l|l|l|l|l|l|}
\hline \multirow{2}{*}{$\begin{array}{l}\text { Nama } \\
\text { Karyawan }\end{array}$} & \multicolumn{4}{|l}{ Kriteria } & \multicolumn{4}{l|}{} \\
\cline { 2 - 6 } & Safety & Quality & $\begin{array}{l}\text { Delivery/ } \\
\text { Inventory }\end{array}$ & $\begin{array}{l}\text { Cost/Man } \\
\text { Hor } \\
\text { Reduction }\end{array}$ & $\begin{array}{l}\text { Innovation/ } \\
\text { Creativity }\end{array}$ \\
\hline A1 & 0,566 & 0,625 & 0,745 & 0,728 & 0,64 \\
\hline A2 & 0,424 & 0,469 & 0,596 & 0,485 & 0,64 \\
\hline A3 & 0,707 & 0,625 & 0,298 & 0,485 & 0,426 \\
\hline
\end{tabular}

4. Menghitung Matriks Keputusan Rating Bobot Ternormalisasi Dengan Persamaan $y_{i j}=w_{i} \mathrm{X} r_{i j}$

Setelah nilai matriks ternormalisasi didapat maka dilakukan perhitungan untuk mencari rating bobot ternormalisasi. Pada langkah ini yang dilakukan adalah mengalikan setiap nilai matriks ternormalisasi dengan nilai bobot setiap kriteria. Sehingga diperoleh perhitungan untuk mencari rating bobot ternormalisasi sebagai berikut:

$$
\begin{aligned}
& y_{i j}=5 \times 0,566=2,828 \\
& y_{i j}=5 \times 0,424=2,121 \\
& y_{i j}=5 \times 0,707=3,536 \\
& y_{i j}=5 \times 0,625=3,123 \\
& y_{i j}=5 \times 0,469=2,343 \\
& y_{i j}=5 \times 0,625=3,123
\end{aligned}
$$

$$
\begin{aligned}
& y_{i j}=5 \times 0,745=3,727 \\
& y_{i j}=5 \times 0,596=2,981 \\
& y_{i j}=5 \times 0,298=1,491 \\
& y_{i j}=5 \times 0,728=3,638 \\
& y_{i j}=5 \times 0,485=2,425 \\
& y_{i j}=5 \times 0,485=2,425 \\
& y_{i j}=5 \times 0,64=3,198 \\
& y_{i j}=5 \times 0,64=3,198 \\
& y_{i j}=5 \times 0,426=2,132
\end{aligned}
$$

Hasil dari nilai bobot ternormalisasi dapat dilihat pada tabel 4 berikut:

TABEL 4

\section{NILAI BOBOT TERNORMALISASI}

\begin{tabular}{|l|l|l|l|l|l|}
\hline \multirow{2}{*}{$\begin{array}{l}\text { Kama } \\
\text { Karyawan }\end{array}$} & \multicolumn{4}{|l|}{ Kriteria } & \multicolumn{4}{l|}{} \\
\cline { 2 - 6 } & Safety & Quality & $\begin{array}{l}\text { Delivery/ } \\
\text { Inventory }\end{array}$ & $\begin{array}{l}\text { Cost/Man } \\
\text { Hor } \\
\text { Reduction }\end{array}$ & $\begin{array}{l}\text { Innovation/ } \\
\text { Creativity }\end{array}$ \\
\hline A1 & 2,828 & 3,123 & 3,727 & 3,638 & 3,198 \\
\hline A2 & 2,121 & 2,343 & 2,981 & 2,425 & 3,198 \\
\hline A3 & 3,536 & 3,123 & 1,491 & 2,425 & 2,132 \\
\hline
\end{tabular}

5. Menentukan solusi ideal positif dan negatif berdasarkan nilai matriks terbobot

Untuk mencari solusi ideal positif adalah nilai tertinggi dari setiap kriteria pada matriks ternormalisasi terbobot, sedangkan untuk mencari solusi ideal negatif adalah nilai terendah untuk setiap kriteria pada matriks terbobot.

TABEL 5

SOLUSI IDEAL POSITIF FAN NEGATIF

\begin{tabular}{|l|l|l|l|l|l|}
\hline $\begin{array}{c}\text { Ideal posistif } \\
\text { dan negatif }\end{array}$ & Safety & Quality & $\begin{array}{l}\text { Delivery/ } \\
\text { Inventory }\end{array}$ & $\begin{array}{l}\text { Cost/ } \\
\text { Man Hour } \\
\text { Reduction }\end{array}$ & $\begin{array}{l}\text { Innovation/ } \\
\text { Creativity }\end{array}$ \\
\hline ideal positif & 3.536 & 3.123 & 3.727 & 3.638 & 3.198 \\
\hline ideal negatif & 2.121 & 2.343 & 1.491 & 2.425 & 2.132 \\
\hline
\end{tabular}

6. Menentukan jarak antara nilai bobot ternormalisasi terhadap solusi ideal positif dan negative

Setelah nilai ideal positif dan negatif dari setiap kriteria didapatkan selanjutnya dilakukan perhitungan untuk mencari jarak antara nilai bobot ternormalisasi terhadap solusi ideal positif dan solusi ideal ngatif. Sehingga di lakukan perhitungan sebagai berikut:

$$
D_{i}^{+}=\sqrt{\sum_{i=1}^{n}\left(y_{i}^{+}-y_{i j}\right)^{2}}
$$




\begin{tabular}{|c|c|c|c|}
\hline $\begin{array}{l}D_{i}^{+}=\sqrt{(3,536-2,828)^{2}+(3,123-3,123)^{2}+(3,727-3,727)^{2}}+ \\
(3,638-3,638)^{2}+(3,198-3,198)^{2}=0,708\end{array}$ & 2 & $\mathrm{~A} 2$ & 0,4596 \\
\hline $\begin{array}{l}D_{i}^{+}=\sqrt{(3,536-2,121)^{2}+(3,123-2,343)^{2}+(3,727-2,981)^{2}}+ \\
(3,638-2,425)^{2}+(3,198-3,198)^{2}=2,154\end{array}$ & 3 & A3 & 0,3695 \\
\hline
\end{tabular}

$(3,638-2,425)^{2}+(3,198-3,198)^{2}=2,154$

$D_{i}^{+}=\sqrt{(3,536-3,536)^{2}+(3,123-3,123)^{2}+(3,727-1,491)^{2}}+$ $(3,638-2,425)^{2}+(3,198-2,132)^{2}=2,758$

Sedangkan untuk mencari jarak solusi ideal negatif adalah sebagai berikut:

$$
D_{i}^{-}=\sqrt{\sum_{i=1}^{n}\left(y_{i j}-y_{i}^{-}\right)^{2}}
$$

$D_{i}^{+}=\sqrt{(2,121-2,828)^{2}+(2,343-3,123)^{2}+(1,491-3,727)^{2}}+$ $(2,425-3,638)^{2}+(2,132-3,198)^{2}=2,952$

$D_{i}^{+}=\sqrt{(2,121-2,121)^{2}+(2,343-2,343)^{2}+(1,491-2,981)^{2}}+$ $(2,425-2,425)^{2}+(2,132-3,198)^{2}=1,832$

$D_{i}^{+}=\sqrt{(2,121-3,536)^{2}+(2,343-3,123)^{2}+(1,491-1,491)^{2}}+$ $(2,425-2,425)^{2}+(2,132-2,132)^{2}=1,615$

Dari perhitungan diatas didapatkan jarak antara nilai bobot ternormalisasi terhadap solusi ideal positif dan solusi ideal negatif.

\section{TABLE 6}

\section{JARAK ANTARA NILAI BOBOT TERNORMALISASI}

\begin{tabular}{|l|l|}
\hline$D+$ & $D-$ \\
\hline 0.708 & 2.952 \\
\hline 2.154 & 1.832 \\
\hline 2.758 & 1.616 \\
\hline
\end{tabular}

7. Menghitung nilai preferensi untuk setiap alternative

Selanjutnya adalah mencari hasil akhir untuk menentukan improvement terbaik dengan melakukan perhitungan sebagai berikut:

$$
V_{i}=\frac{D_{i}^{-}}{D_{i}^{-}+D_{i}^{+}}
$$

$V_{1}=\frac{2,952}{2,952+0,708}=0,8066$

$V_{2}=\frac{1,832}{1,832+2,153}=0,4596$

$V_{3}=\frac{1,616}{1,616+2,756}=0,3695$

Berdasarkan nilai $\mathrm{V}$ yang telah dicari maka didapatkan nilai pada setiap aktivitas kaizen yang dapat dilihat pada tabel 7 berikut:

TABLE 7

HASIL AKHIR PENILAIAN

\begin{tabular}{|l|l|l|}
\hline No & Nama karyawan & Nilai \\
\hline 1 & A1 & 0,8066 \\
\hline
\end{tabular}

\section{Perancangan Diagram Konteks}

Diagram konteks merupakan level tertinggi dari DFD yang menggambarkan seluruh input ke sistem atau ouput dari sistem. Diagram konteks ini akan memberi gambaran tentang keseluruhan sistem.

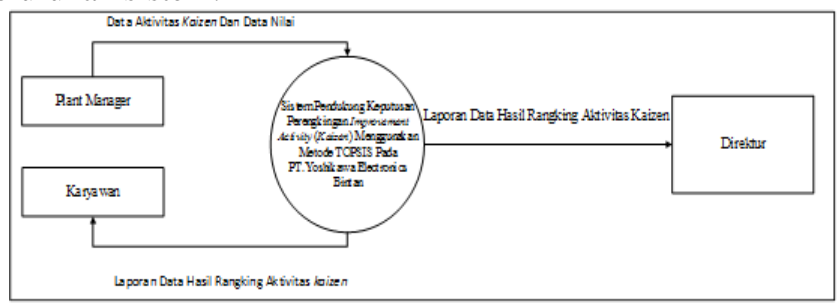

Gambar 1 Diagram Konteks

\section{Perancangan (DFD)}

DFD atau Data Flow Diagram merupakan gambaran suatu sistem yang telah ada maupun sistem baru yang dikembangkan secara logika tanpa mempertimbangkan lingkungan fisik dimana data tersebut mengalir.

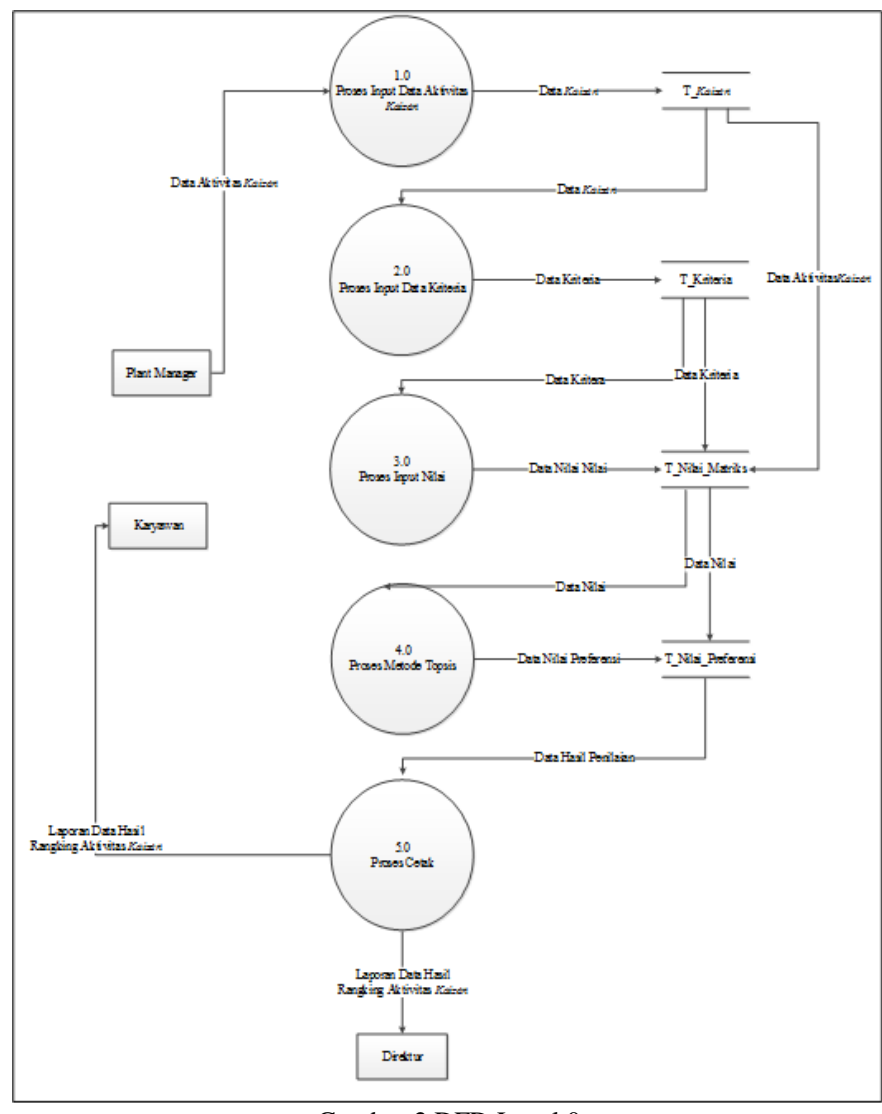

Gambar 2 DFD Level 0 


\section{E. Implementasi Sistem}

1. Halaman Login

Halaman login adalah halaman yang digunakan ketika admin pertama kali masuk aplikasi sistem pendukung keputusan untuk perengkingan kaizen. Tampilan halaman login dapat dilihat pada gambar 3 berikut:

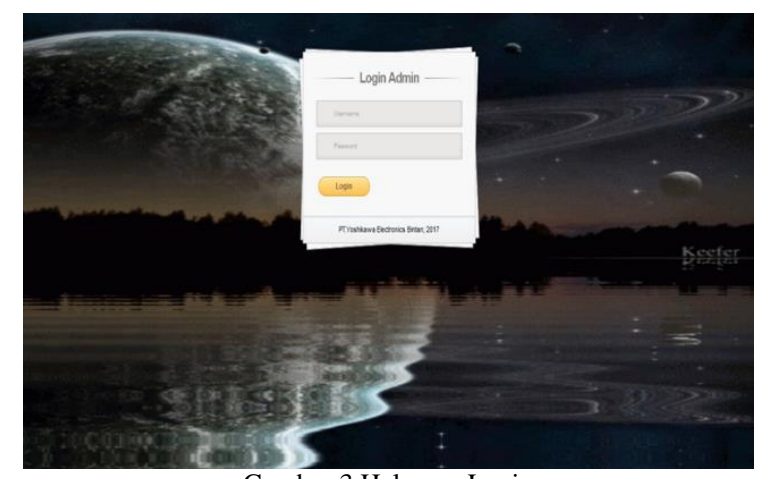

Gambar 3 Halaman Login

\section{Halaman Kriteria}

Gambar 4 adalah tampilan halaman kriteria yang digunakan untuk melihat data kriteria yang telah di simpan kedalam database dan disediakan button untuk menambah data krtiteria, edit kriteria dan hapus kriteria.

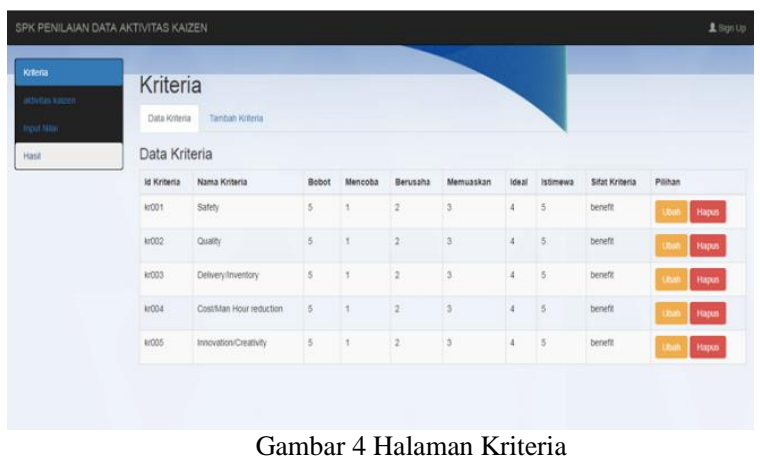

\section{Halaman Aktivitas Kaizen}

Gambar 6 adalah tampilan halaman aktivitas kaizen yang digunakan oleh admin untuk melihat data aktivitas kaizen, button untuk menambah data aktivitas kaizen, edit data kaizen dan hapus data kaizen.

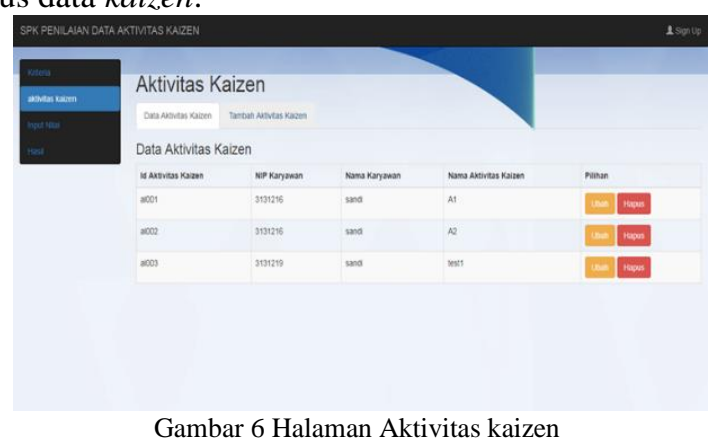

\section{Halaman Input Nilai}

Gambar 7 adalah tampilan halaman input nilai yang digunakan oleh admin untuk menginput nilai setiap aktivitas kaizen dan menyimpan kedalam database.

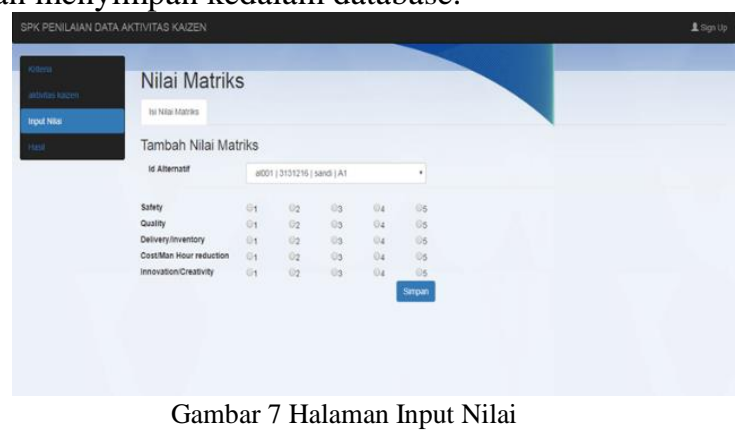

\section{Halaman Hasil}

Gambar 5.10 adalah tampilan halaman hasil yang digunakan oleh admin untuk meilhat data hasil penilaian yang sudah dilakukan. Dimana pada halaman ini dapat dilihat hasil perhitungan nilai matriks ternormalisasi, nilai bobot ternormalisasi, matriks ideal positif/negatif, jarak solusi ideal positif/negative dan hasil nilai preverensi.

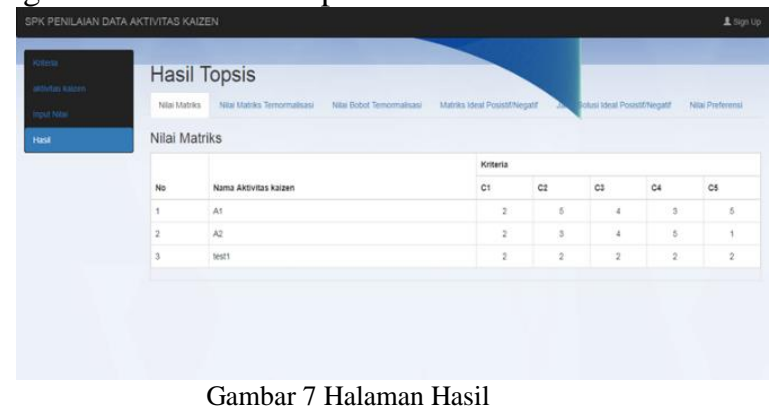

\section{KESIMPULAN}

Setelah penelitian ini selesai dilakukan, peneliti dapat membuat beberapa kesimpulan di bawah ini:

A. Berdasarkan hasil pengujian aplikasi sistem pendukung keputusan untuk perengkingan kaizen dengan memasukkan alternatif yang ingin dinilai dapat membantu bagian plant manager dalam menentukan rangking kaizen.

B. Aplikasi sistem pendukung keputusan untuk perengkingan kaizen dapat membantu bagian plant manager dalam meminimalis waktu dalam proses penilaian kaizen.

C. Proses penilaian yang tadinya masih menggunakan cara manual, sekarang sudah di permudah dengan adanya aplikasi sistem pendukung keputusan perengkingan kaizen yang secara otomatis sistem akan melakukan penilaian.

D. Sistem dilengkapi dengan feature print laporan hasil rangking secara langsung dari sistem sehingga membantu bagian plant manager dalam pembuatan laporan yang sebelumnya masih menggunakan cara manual.

\section{REFERENSI}

[1] Andrea Adelheid, Website No 1: Cara Mudah Bikin Website \& Promosi Ke Seo, Mediakom, 2015, Yogyakarta. 
Bangkit Indonesia, Vol. VIII, No.01, Bulan Maret 2019

[2] Handayani, Kaizen Culture, Education Dan Training, Irwing Professional, 2015, New York.

[3] Hanif Al Fatta, Analisis Dan Perancangan Sistem Informasi, Andi, 2017, Yogyakarta

[4] Janner Simarmata: Rekayasa Perangkat Lunak, Andi Publisher, 2012, Yogyakarta.

[5] Linda Marlinda, Sistem Basis Data, Andi, 2014, Yogyakarta.

[6] M. Rudyanto Arief, Pemograman Web Dinamis Menggunakan PHP Dan MySQL, 2015, Jakarta

[7] Nugroho Adi, Rekayasa Perangkat Lunak Berbasis Objek, Andi Publisher, 2016, Yogyakarta.

[8] Nugroho Adi, Pemrograman PHP dan My SQL Untuk Pemula, Madcoms, 2016, Yogyakarta.

[9] Sutanta, Basis Data Dalam Tinjauan Konseptual, Andi Publisher, 2014, Yogyakarta.

[10] Tata Sutabri, Sistem Informasi Manajemen, Andi Publisher, 2011, Yogyakarta. 